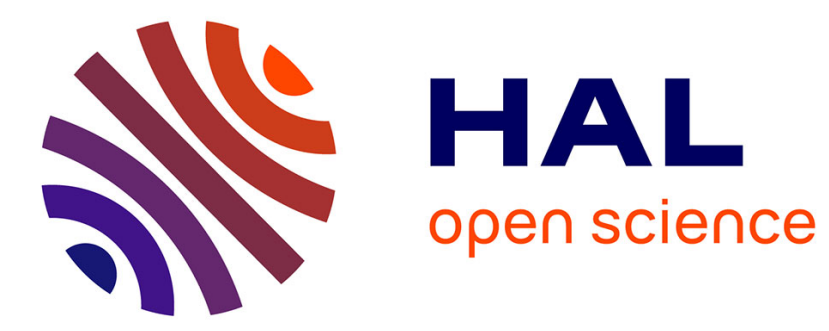

\title{
The first cyclopentadienyl complex of uranyl
}

Jérôme Maynadie, J.C. Berthet, Pierre Thuéry, Michel Ephritikhine

\section{To cite this version:}

Jérôme Maynadie, J.C. Berthet, Pierre Thuéry, Michel Ephritikhine. The first cyclopentadienyl complex of uranyl. Chemical Communications, 2007, pp.486-488. 10.1039/b617700j . cea-00168563

\section{HAL Id: cea-00168563 https: / hal-cea.archives-ouvertes.fr/cea-00168563}

Submitted on 29 Aug 2007

HAL is a multi-disciplinary open access archive for the deposit and dissemination of scientific research documents, whether they are published or not. The documents may come from teaching and research institutions in France or abroad, or from public or private research centers.
L'archive ouverte pluridisciplinaire HAL, est destinée au dépôt et à la diffusion de documents scientifiques de niveau recherche, publiés ou non, émanant des établissements d'enseignement et de recherche français ou étrangers, des laboratoires publics ou privés. 


\title{
The first cyclopentadienyl complex of uranyl
}

\section{Jérôme Maynadié, Jean-Claude Berthet,* Pierre Thuéry and Michel Ephritikhine}

\author{
Received (in Cambridge, UK) 5th December 2006, Accepted 15th December 2006 \\ First published as an Advance Article on the web 22nd December 2006 \\ DOI: $10.1039 / \mathrm{b} 617700 \mathrm{j}$
}

The U(IV) linear pentacyano metallocene $\left[\mathrm{U}\left(\mathrm{C}_{5} \mathrm{Me}_{5}\right)_{2}(\mathrm{CN})_{5}\right]$ $\left[\mathrm{NEt}_{4}\right]_{3}$ reacted with 2 molar equivalents of pyridine $\mathrm{N}$-oxide in $\mathrm{THF}$ or acetonitrile to give the $\mathrm{U}(\mathrm{VI})$ complex $\left[\mathrm{UO}_{2}\left(\mathrm{C}_{5} \mathrm{Me}_{5}\right)(\mathrm{CN})_{3}\right]\left[\mathrm{NEt}_{4}\right]_{2}$, the first uranyl species containing the cyclopentadienyl ligand; the crystal structure revealed that the steric effects of the $\left(\mathrm{C}_{5} \mathrm{Me}_{5}\right)$ ligand force the $\left\{\mathrm{UO}_{2}\right\}^{2+}$ ion to deviate from linearity.

The most extended classes of organometallic compounds of $\mathrm{d}$ transition metals and f-elements contain the cyclopentadienyl ligand $\left(\mathrm{C}_{5} \mathrm{H}_{5}\right)^{-}$or its alkyl substituted derivatives $\left(\mathrm{C}_{5} \mathrm{H}_{5-n} \mathrm{R}_{n}\right)^{-}$. These anions, with their tunable steric and electronic effects, proved beneficial for the stabilization of metal species in both low and high oxidation states, and favored the emergence of novel structural and reactivity patterns. ${ }^{1}$ Cyclopentadienyl ligands are also ubiquitous in uranium chemistry, which has witnessed a spectacular development during the last decade with the synthesis, structure and reactions of low-valent mono-, bis- and tris(pentamethylcyclopentadienyl) complexes. ${ }^{2-6}$ Highlights in these advances concern the chemical behavior of the U(III) complexes $\mathrm{U}\left(\mathrm{C}_{5} \mathrm{Me}_{5}\right)_{3}$ and $\left[\mathrm{U}\left(\mathrm{C}_{5} \mathrm{Me}_{5}\right)_{2}\right]\left[\mathrm{BPh}_{4}\right]$, which are able to activate $\mathrm{CO}$, $\mathrm{N}_{2}$ and $\mathrm{N}_{3}{ }^{-4,5}$ and the discovery of the U(IV) precursors $\left[\mathrm{U}\left(\mathrm{C}_{5} \mathrm{Me}_{5}\right)_{2}(\mathrm{NCMe})_{5}\right] \mathrm{X}_{2}\left(\mathrm{X}=\mathrm{I}, \mathrm{OTf}, \mathrm{BPh}_{4}\right)$ which represent a novel type of linear metallocenes. ${ }^{6}$ These results were an incitement to perform theoretical calculations which clarified the crucial role of the $5 \mathrm{f}$ orbitals in the metal-ligand interaction. ${ }^{7}$

Stabilization of high-valent organouranium complexes, especially those of the trans dioxo uranyl ion $\left\{\mathrm{UO}_{2}\right\}^{2+}$ which is the most stable species in the +6 oxidation state, is a long-standing challenge. All attempts to synthesize cyclopentadienyl uranyl compounds were unsuccessful, ${ }^{2,8}$ leading to the formation of dark orange solutions and the eventual decomposition of the uranyl ion into unidentified U(IV) species. Such reactions have been however recently revisited. In an attempt to produce the dioxo species $\mathrm{UO}_{2}\left(\mathrm{Cp}^{\prime}\right)_{2}\left(\mathrm{Cp}^{\prime}=1,2,4-t \mathrm{Bu}_{3} \mathrm{C}_{5} \mathrm{H}_{2}\right)$ by addition of pyridine $N$-oxide onto $\mathrm{U}\left(\mathrm{Cp}^{\prime}\right)_{2} \mathrm{Cl}_{2} \mathrm{~K}$, Duval et al. isolated the polynuclear compound $\mathrm{U}_{6}\left(\mathrm{Cp}^{\prime}\right)_{4} \mathrm{O}_{13}$ (bipy) $)_{2}$, a unique $\mathrm{U}(\mathrm{v})$ oxide with an isopolyoxometalate core, ${ }^{9}$ whereas we found that reactions of $\mathrm{UO}_{2} \mathrm{X}_{2}(\mathrm{X}=\mathrm{OTf}, \mathrm{I})$ with $\mathrm{C}_{5} \mathrm{R}_{5}{ }^{-}$anions $(\mathrm{R}=\mathrm{H}, \mathrm{Me})$ constitute convenient routes to stable neutral and anionic pentavalent uranyl(v) complexes. ${ }^{10}$ These results question the stability of the $\mathrm{UO}_{2}\left(\mathrm{C}_{5} \mathrm{R}_{5}\right)_{n} \mathrm{X}_{2-n}(n=1,2)$ species and/or the methods of their preparation. Moreover, one could consider that such complexes with an $\eta^{5}$-coordinated cyclopentadienyl group might not be attainable for steric and electronic reasons, in view of the classical

Service de Chimie Moléculaire, DSM, DRECAM, CNRS URA 331,

Laboratoire Claude Fréjacques, CEA Saclay, Gif-sur-Yvette, 91191,

France.E-mail: jean-claude.berthet@cea.fr; Fax: 3316908 640;

Tel: 33169086042. bipyramidal geometry of uranyl complexes in which the ligands are located in the equatorial plane.

Here we present the synthesis and crystal structure of $\left[\mathrm{UO}_{2}\left(\mathrm{C}_{5} \mathrm{Me}_{5}\right)(\mathrm{CN})_{3}\right]\left[\mathrm{NEt}_{4}\right]_{2}$ (1). In addition to being the first cyclopentadienyl uranyl complex, $\mathbf{1}$ is the sole cyclopentadienyl dioxo metal compound with an almost linear $\mathrm{MO}_{2}$ fragment; the only other monocyclopentadienyl dioxo complexes present in the Cambridge Structural Database ${ }^{11}$ which exhibit a bent $\mathrm{MO}_{2}$ unit exist almost exclusively with $\mathrm{M}=\mathrm{Mo}$ or $\mathrm{W}$.

We have recently reported that the bright orange linear metallocene $\left[\mathrm{U}\left(\mathrm{C}_{5} \mathrm{Me}_{5}\right)_{2}(\mathrm{CN})_{5}\right]\left[\mathrm{NEt}_{4}\right]_{3}$, a rare example of a cyanide complex of a $5 \mathrm{f}$ element, ${ }^{12}$ could be obtained from the reaction of $\mathrm{U}\left(\mathrm{C}_{5} \mathrm{Me}_{5}\right)_{2} \mathrm{X}_{2}$ or $\left[\mathrm{U}\left(\mathrm{C}_{5} \mathrm{Me}_{5}\right)_{2}(\mathrm{NCMe})_{5}\right] \mathrm{X}_{2}(\mathrm{X}=\mathrm{I}$, OTf $)$ and $\mathrm{NEt}_{4} \mathrm{CN}^{6}{ }^{6} \uparrow$ In one experiment in THF, brown crystals were deposited and the X-ray diffraction analysis revealed that these crystals were of the unexpected uranyl complex $\left[\mathrm{UO}_{2}\left(\mathrm{C}_{5} \mathrm{Me}_{5}\right)(\mathrm{CN})_{3}\right]\left[\mathrm{NEt}_{4}\right]_{2}$ (1), which certainly resulted from accidental oxidation of the parent pentacyano U(IV) complex with adventitious traces of oxygen and/or water. The rational and reproducible synthesis of $\mathbf{1}$ was achieved by reacting the tetravalent metallocene $\left[\mathrm{U}\left(\mathrm{C}_{5} \mathrm{Me}_{5}\right)_{2}(\mathrm{CN})_{5}\right]\left[\mathrm{NEt}_{4}\right]_{3}$ with 2 molar equivalents of pyridine $\mathrm{N}$-oxide (pyO), \& a well known oxygen transfer reagent useful for the preparation of low- and high-valent actinide oxo complexes. ${ }^{9,13}$ This synthesis of $\mathbf{1}$ requires the transfer of two electrons, probably coming from a $\mathrm{C}_{5} \mathrm{Me}_{5}{ }^{-}$and a $\mathrm{CN}^{-}$ion. After $3 \mathrm{~h}$ in refluxing THF, brown crystals of $\mathbf{1}$ were deposited in almost quantitative yield and were characterized by X-ray diffraction analysis; this reaction was much more rapid in acetonitrile, being complete after $1 \mathrm{~h}$ at $110{ }^{\circ} \mathrm{C}$. However, in both cases, 1 could not be separated from the released salt $\mathrm{NEt}_{4} \mathrm{CN}$ which has similar solubility. Other preparations of $\mathbf{1}$ were considered, by oxidation of trivalent metallocenes with pyO, or by transformation of uranyl(VI) precursors. Thus, reaction of $\left[\mathrm{U}\left(\mathrm{C}_{5} \mathrm{Me}_{5}\right)_{2}(\mathrm{CN})_{3}\right]\left[\mathrm{NEt}_{4}\right]_{2}$ with 2 equivalents of pyO in acetonitrile, or treatment of $\mathrm{UO}_{2}(\mathrm{OTf})_{2}$ with 3 equivalents of $\mathrm{Bu}_{4} \mathrm{NCN}$ in THF, followed by addition of 1 equivalent of $\mathrm{KC}_{5} \mathrm{Me}_{5}$, afforded brown solutions of unknown products that are under investigation. Recently, similar attempts to prepare $\mathrm{UO}_{2}\left(\mathrm{C}_{5} \mathrm{R}_{n} \mathrm{H}_{5-n}\right) \mathrm{X}$ compounds, from halide and triflate $\mathrm{U}(\mathrm{III})$ and $\mathrm{U}(\mathrm{VI})$ precursors, generated unexpected $\mathrm{U}(\mathrm{v})$ derivatives. ${ }^{9,10}$

Single crystals of 1 were picked up from their mixture with the released salt. A view of the anion $\left[\mathrm{UO}_{2}\left(\mathrm{C}_{5} \mathrm{Me}_{5}\right)(\mathrm{CN})_{3}\right]^{2-}$ of $\mathbf{1}$ is shown in Fig. 1 with selected bond lengths and angles.§ Considering the cyclopentadienyl ligand as monodentate, the configuration of the complex is distorted tetragonal bipyramidal (or octahedral) with the almost linear $\mathrm{UO}_{2}$ fragment perpendicular to the equatorial plane defined by the $\mathrm{U}$ and three coordinating $\mathrm{C}$ atoms of the cyanide ions and the centroid of the $\mathrm{C}_{5} \mathrm{Me}_{5}$ ring. In compound 1, as well as in $\left[\mathrm{UO}_{2}(\mathrm{CN})_{5}\right]\left[\mathrm{NEt}_{4}\right]_{3},{ }^{12}$ the $\left\{\mathrm{UO}_{2}\right\}^{2+}$ ion is 


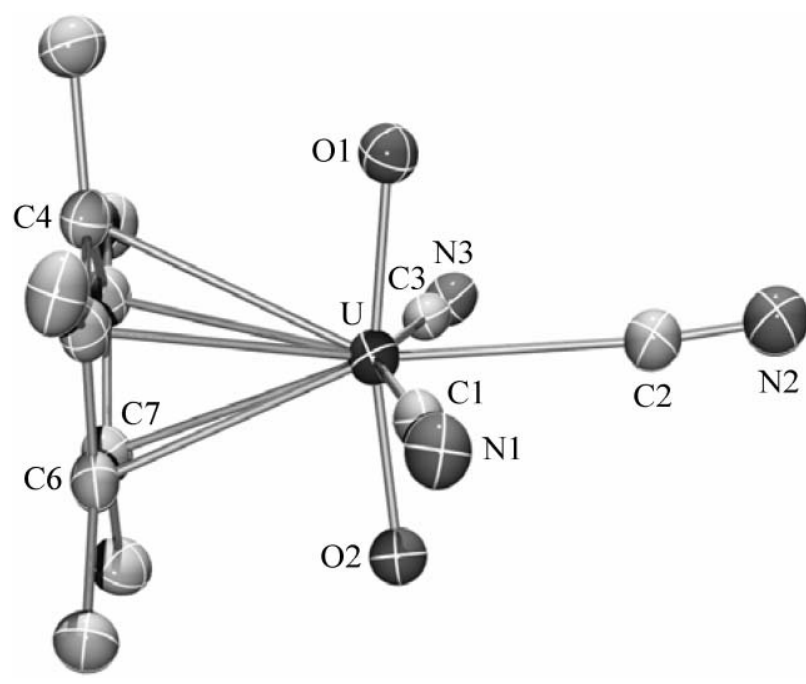

Fig. 1 View of the anion $\left[\mathrm{UO}_{2}\left(\mathrm{C}_{5} \mathrm{Me}_{5}\right)(\mathrm{CN})_{3}\right]^{2-}$ of $\mathbf{1}$ with displacement ellipsoids at the $50 \%$ probability level. Hydrogen atoms are omitted for clarity. Selected bond lengths $(\AA)$ and angles ( $\left.{ }^{\circ}\right)$ : U-O1 1.784(2), U-O2 1.7835(19), U-C1 2.608(3), U-C2 2.563(3), U-C3 2.598(3), U-centroid 2.568, O1-U-O2 168.40(9), C1-U-C2 78.02(10), C2-U-C3 82.07(10), O1U-centroid 94.0, O2-U-centroid 97.5, C1-U-centroid 98.4, C2-Ucentroid 174.4, C3-U-centroid 101.7.

surrounded only by carbon atoms. Deviation from linearity by $11.6^{\circ}$ of the $\mathrm{UO}_{2}$ fragment originates from short contacts between O1 and C4 (2.83 $\AA$ ) and O2 and C6 and C7 (2.95 and $2.97 \AA)$. Similar steric constraints in the equatorial plane force the lateral cyanides to form a C1-U-C3 angle of $159.75(9)^{\circ}$ instead of being in a trans position; this angle is larger than the corresponding angles in $\left[\mathrm{U}\left(\mathrm{C}_{5} \mathrm{Me}_{5}\right)_{2}(\mathrm{CN})_{3}\right]^{n-}(n=1,2)^{14}$ or $\left[\mathrm{UO}_{2}(\mathrm{CN})_{5}\right]^{3-12}$ which vary from $138^{\circ}$ to $150^{\circ}$. The U-O distances of $1.7835(19)$ and 1.784(2) $\AA$ are typical of electron rich uranyl species. ${ }^{15}$ The cyclopentadienyl ring is perpendicular to the equatorial plane with a U-centroid distance and a mean U-C bond length of 2.568 and 2.84(4) $\AA$, respectively. The U-C $\left(\mathrm{C}_{5} \mathrm{Me}_{5}\right)$ distances are larger than those found in the $\mathrm{U}(\mathrm{VI})$ metallocene complexes $\mathrm{U}\left(\mathrm{C}_{5} \mathrm{Me}_{5}\right)_{2}(=\mathrm{O})\left(=\mathrm{N}-2,6-{ }^{\mathrm{i}} \mathrm{Pr}_{2} \mathrm{C}_{6} \mathrm{H}_{3}\right)_{2} \quad[2.730(6)-2.805(6) \AA]^{16}$ and $\mathrm{U}\left(\mathrm{C}_{5} \mathrm{Me}_{5}\right)_{2}(=\mathrm{NPh})_{2}[2.718(10)-2.746(8) \AA],{ }^{17}$ which exhibit bent $\mathrm{UON}$ and $\mathrm{UN}_{2}$ fragments, and could reflect the dianionic charge of the complex. The U-C distances of the cyanide ligands average 2.59(2) $\AA$, a value which is similar to that of 2.567(11) $\AA$ in the hepta-coordinate $\left[\mathrm{UO}_{2}(\mathrm{CN})_{5}\right]\left[\mathrm{NEt}_{4}\right]_{3}$, the only other uranyl cyanide complex. ${ }^{12}$

Compound $\mathbf{1}$ is a rare example of a uranyl complex containing $\mathrm{U}-\mathrm{C}$ bonds, with the aforementioned cyanide compound, the bisiminophosphorane complex $\mathrm{UO}_{2} \mathrm{Cl}\left(\eta^{3}-\mathrm{CH}\left\{\mathrm{Ph}_{2} \mathrm{PNSiMe}_{3}\right\}_{2}\right)$ (THF) and its derivatives, ${ }^{18}$ and a few $N$-heterocyclic carbene complexes. ${ }^{19}$ More outstandingly, the structure of $\mathbf{1}$ represents a novel coordination geometry for the uranyl ion which almost invariably adopts a polygonal bipyramidal configuration; ${ }^{20}$ the carbon atoms of the $\mathrm{C}_{5} \mathrm{Me}_{5}$ ring are much displaced from the equatorial plane, by 1.494(6) $\AA$ for C4 and 0.68(3) $\AA$ on average for the other carbon atoms. The greatest displacement of a coordinating atom from the equatorial plane of the $\left\{\mathrm{UO}_{2}\right\}^{2+}$ ion, $0.82 \AA$, was previously observed in $\left[\mathrm{H}_{2} \mathrm{NBu}_{2}{ }_{2}\right]\left[\mathrm{UO}_{2}\left(p-\mathrm{Bu}^{\mathrm{t}}-\right.\right.$ hexahomotrioxacalix[3]arene)]. ${ }^{21}$
The ${ }^{1} \mathrm{H}$ NMR spectrum of $\mathbf{1}$ in acetonitrile exhibits a signal attributed to the $\mathrm{C}_{5} \mathrm{Me}_{5}$ ligand at $\delta 4.36$, a value close to those found in the aforementioned U(VI) metallocenes. ${ }^{16,17}$ The IR spectrum displays a strong absorption band at $905 \mathrm{~cm}^{-1}$ assigned to the $\mathrm{UO}_{2}$ stretching vibration mode. This value can be compared with those found in the electron rich species $\left[\mathrm{UO}_{2} \mathrm{X}_{4}\right]^{2-}[\mathrm{X}=\mathrm{Cl}$ $\left.\left(908 \mathrm{~cm}^{-1}\right), \mathrm{Br}\left(916 \mathrm{~cm}^{-1}\right)\right]^{22}$ or $\left[\mathrm{UO}_{2}(\mathrm{CN})_{5}\right]^{3-}\left(911 \mathrm{~cm}^{-1}\right){ }^{12}$ The two major $v(\mathrm{CN})$ absorption bands at 2090 and $2069 \mathrm{~cm}^{-1}$ can be compared with those in $\left[\mathrm{UO}_{2}(\mathrm{CN})_{5}\right]^{3-}\left(2190,2180\right.$ and $\left.2070 \mathrm{~cm}^{-1}\right)$ or in the bent cyano metallocenes $\left[\mathrm{U}\left(\mathrm{C}_{5} \mathrm{Me}_{5}\right)_{2}(\mathrm{CN})_{3}\right]^{n-}(n=1,2)$ $\left(2050-2190 \mathrm{~cm}^{-1}\right){ }^{14}$

In conclusion, we found that oxidation of the uranium(IV) cyano metallocene $\left[\mathrm{U}\left(\mathrm{C}_{5} \mathrm{Me}_{5}\right)_{2}(\mathrm{CN})_{5}\right]\left[\mathrm{NEt}_{4}\right]_{3}$ with pyridine $N$-oxide gave $\left[\mathrm{UO}_{2}\left(\mathrm{C}_{5} \mathrm{Me}_{5}\right)(\mathrm{CN})_{3}\right]\left[\mathrm{NEt}_{4}\right]_{2}$ (1), a novel uranyl cyanide compound and the first cyclopentadienyl complex of the $\left\{\mathrm{UO}_{2}\right\}^{2+}$ ion. Such soluble compounds may be useful in the building of new polynuclear assemblages involving U-CN-M bridges $(\mathrm{M}=\mathrm{d}$ - or $\mathrm{f}$-element) which attract much attention for their peculiar physico-chemical properties. Although 1 cannot be considered as a convenient precursor for extending the cyclopentadienyl chemistry of uranyl, its formation strongly suggests that other $\left[\mathrm{UO}_{2}\left(\mathrm{C}_{5} \mathrm{R}_{5}\right)\right]^{+}$species, with varying coordination environments, could be attainable. We are currently trying to isolate stable $\mathrm{UO}_{2}\left(\mathrm{C}_{5} \mathrm{R}_{5}\right) \mathrm{X}(\mathrm{X}=$ halide) complexes as well as the pentavalent congeners $\mathrm{UO}_{2}\left(\mathrm{C}_{5} \mathrm{R}_{5}\right)$. Both types of compounds should be promising precursors for further developments in the organometallic chemistry of uranium and for the preparation of soluble uranium oxides, which represent an attractive field of investigation for their fundamental aspects and applications.

We thank the Direction de l'Energie Nucléaire of the Commissariat à l'Energie Atomique for its financial support.

\section{Notes and references}

$\uparrow$ Synthesis of $\left[\mathrm{U}\left(\mathrm{C}_{5} \mathrm{Me}_{5}\right)_{2}(\mathrm{CN})_{5}\right]\left[\mathrm{NEt}_{4}\right]_{3}$ : A flask was charged with $\mathrm{U}\left(\mathrm{C}_{5} \mathrm{Me}_{5}\right)_{2}(\mathrm{OTf})_{2}(157.0 \mathrm{mg}, 0.195 \mathrm{mmol})$ and $\mathrm{NEt}_{4} \mathrm{CN}(162.1 \mathrm{mg}$, $0.975 \mathrm{mmol}$ ) and $\mathrm{MeCN}$ was condensed in. After stirring for $30 \mathrm{~min}$ at $20{ }^{\circ} \mathrm{C}$, the solvent was evaporated off and THF $(30 \mathrm{~mL})$ was condensed into the flask. The mixture was heated at $50{ }^{\circ} \mathrm{C}$ for $1 \mathrm{~h}$ and the orange powder of the product was filtered off, washed three times with THF $(20 \mathrm{~mL})$ and dried under vacuum (150 mg, $0.146 \mathrm{mmol}, 75 \%) .{ }^{1} \mathrm{H}$ NMR $\left(200 \mathrm{MHz}, 23{ }^{\circ} \mathrm{C}, \mathrm{MeCN}-d_{3}\right): \delta 24.35$ (br s, $w_{1 / 2}=360 \mathrm{~Hz}, 30 \mathrm{H}, \mathrm{C}_{5} \mathrm{Me}_{5}$ ), 2.40 (q, $\left.24 \mathrm{H}, \mathrm{NCH}_{2} \mathrm{CH}_{3}\right), 0.69$ (s, $w_{1 / 2}=20 \mathrm{~Hz}, 36 \mathrm{H}, \mathrm{NCH}_{2} \mathrm{CH}_{3}$ ). Found: C, 56.86; H, 8.58; N, 11.08. $\mathrm{C}_{49} \mathrm{H}_{90} \mathrm{~N}_{8} \mathrm{U}$ requires $\mathrm{C}, 57.18 ; \mathrm{H}, 8.81 ; \mathrm{N}$, $10.89 \%$.

\$ Synthesis of 1: An NMR tube was charged with $\left[\mathrm{U}\left(\mathrm{C}_{5} \mathrm{Me}_{5}\right)_{2}(\mathrm{CN})_{5}\right]$ $\left[\mathrm{NEt}_{4}\right]_{3}(15 \mathrm{mg}, 14.6 \mathrm{mmol})$ and pyridine $N$-oxide $(2.8 \mathrm{mg}, 29.2 \mathrm{mmol})$ and THF $(0.5 \mathrm{~mL})$ was condensed in it. The orange suspension was heated for $3 \mathrm{~h}$ at $110{ }^{\circ} \mathrm{C}$, leading to an almost colourless solution and brown crystals of 1 contaminated with colourless crystals of $\mathrm{NEt}_{4} \mathrm{CN}$. ${ }^{1} \mathrm{H}$ NMR $\left(200 \mathrm{MHz}, 23{ }^{\circ} \mathrm{C}, \mathrm{MeCN}-d_{3}\right): \delta 4.36\left(\mathrm{~s}, w_{1 / 2}=3 \mathrm{~Hz}, 30 \mathrm{H}, \mathrm{C}_{5} \mathrm{Me}_{5}\right), 4.11$ (q, $\left.\mathrm{J} 7 \mathrm{~Hz}, 24 \mathrm{H}, \mathrm{NCH}_{2}\right), 2.12\left(\mathrm{~m}, 36 \mathrm{H}, \mathrm{NCH}_{2} \mathrm{CH}_{3}\right.$ ). IR spectrum (Nujol): $v_{\mathrm{as}}(\mathrm{UO})=905 \mathrm{~cm}^{-1}(\mathrm{~s})$; a very strong band is also observed at $875 \mathrm{~cm}^{-1}$, $v(\mathrm{CN})=2090,2069 \mathrm{~cm}^{-1}$. The same reaction carried out in $\mathrm{MeCN}-d_{3}$ $(1 \mathrm{~mL})$ led after $1 \mathrm{~h}$ at $110^{\circ} \mathrm{C}$ to a dark red solution which showed the same ${ }^{1} \mathrm{H}$ NMR signals.

$\S$ Crystal data for 1: $\mathrm{C}_{29} \mathrm{H}_{55} \mathrm{~N}_{5} \mathrm{O}_{2} \mathrm{U}, M=743.81$, monoclinic, space group $P 2_{1} / c, a=15.4887(9), b=10.9902(7), c=19.1428(7) \AA, \beta=91.009(3)^{\circ}$, $V=3258.1(3) \AA^{3}, Z=4, \mu($ Mo K $\alpha)=5.013 \mathrm{~mm}^{-1}, 134019$ measured reflections, 6173 independent $\left(R_{\text {int }}=0.028\right), 5177$ with $I>2 \sigma(I)$, 347 parameters, $R 1=0.023, w R 2=0.052$. The data were collected at $100(2) \mathrm{K}$ on a Nonius Kappa-CCD diffractometer with Mo K $\alpha$ radiation. Absorption effects were empirically corrected. CCDC 629734. For crystallographic data in CIF or other electronic format see DOI: $10.1039 / \mathrm{b} 617700 \mathrm{j}$ 
1 (a) Comprehensive Organometallic Chemistry, ed. G. Wilkinson, F. G. A. Stone and E. W. Abel, Pergamon, Oxford, 1995, vol. 1-12; (b) H. Schumann, J. A. Meese-Marktscheffel and L. Esser, Chem. Rev., 1995, 95, 865; (c) M. N. Bochkarev, Coord. Chem. Rev., 2004, 248, 835.

2 (a) C. J. Burns and M. S. Eisen, in The Chemistry of the Actinides and Transactinides Elements, ed. L. R. Morss, N. M. Edelstein and J. Fuger, Springer, Dordrecht (The Netherlands), 3rd edn, 2006, vol. 5, p. 2799; (b) M. Ephritikhine, Dalton Trans., 2006, 2501.

3 L. R. Avens, C. J. Burns, R. J. Butcher, D. L. Clark, J. C. Gordon, A. R. Schake, B. L. Scott, J. G. Watkin and B. D. Zwick, Organometallics, 2000, 19, 451.

4 (a) W. J. Evans and S. A. Kozimor, Coord. Chem. Rev., 2006, 250, 911; (b) W. J. Evans and B. Davis, Chem. Rev., 2002, 102, 2119.

5 W. J. Evans, S. A. Kozimor and J. W. Ziller, Science, 2005, 309, 1835.

6 J. Maynadié, J. C. Berthet, P. Thuéry and M. Ephritikhine, J. Am. Chem. Soc., 2006, 128, 1082.

7 (a) O. T. Summerscale, F. G. N. Cloke, P. B. Hitchcock, J. C. Green and N. Hazari, Science, 2006, 311, 829; (b) M. Roger, L. Belkhiri, P. Thuéry, T. Arliguie, M. Fourmigué, A. Boucekkine and M. Ephritikhine, Organometallics, 2005, 24, 4940; (c) F. G. N. Cloke, J. C. Green and N. Kaltsoyannis, Organometallics, 2004, 23, 832.

8 (a) D. Seyferth, Organometallics, 2004, 23, 3562; (b) C. J. Burns, D. L. Clark, R. J. Donohoe, B. L. Scott and C. D. Tait, Inorg. Chem., 2000, 39, 5464; (c) G. Bombieri, F. Benetollo, E. Klähne and R. D. Fischer, J. Chem. Soc., Dalton Trans., 1983, 1115

9 P. B. Duval, C. J. Burns, D. L. Clark, B. L. Morris, B. L. Scott, J. D. Thompson, E. L. Werkema, L. Jia and R. A. Andersen, Angew. Chem., Int. Ed., 2001, 40, 3358.

10 J. C. Berthet, G. Siffredi, P. Thuéry and M. Ephritikhine, Chem. Commun., 2006, 3184.
11 F. H. Allen, Acta Crystallogr., Sect. B: Struct. Sci., 2002, 58, 380.

12 J.-C. Berthet, P. Thuéry and M. Ephritikhine, Chem. Commun., 2007, DOI: $10.1039 / \mathrm{b} 614226 \mathrm{e}$, and references therein.

13 (a) L. Natrajan, F. Burdet, J. Pécaut and M. Mazzanti, J. Am. Chem Soc., 2006, 128, 7152; (b) J. A. Pool, B. L. Scott and J. L. Kiplinger, J. Am. Chem. Soc., 2005, 127, 1338; (c) G. Zi, L. Jia, E. L. Werkema, M. D. Walter, J. P. Gottfriedsen and R. A. Andersen, Organometallics, 2005, 24, 4251; (d) P. Roussel, R. Boaretto, A. J. Kingsley, N. W. Alcock and P. Scott, J. Chem. Soc., Dalton Trans., 2002, 1423; (e) R. A. Andersen, Inorg. Chem., 1979, 18, 1507.

14 J. Maynadié, N. Barros, J.-C. Berthet, P. Thuéry, L. Maron and M. Ephritikhine, Angew. Chem., Int. Ed., in press.

15 D. L. Clark, S. D. Conradson, R. J. Donohoe, D. W. Keogh, D. E. Morris, P. D. Palmer, R. D. Rogers and C. D. Tait, Inorg. Chem., 1999, 38, 1456.

16 D. S. Arney and C. J. Burns, J. Am. Chem. Soc., 1993, 115, 9840.

17 (a) D. S. Arney, C. J. Burns and D. C. Smith, J. Am. Chem. Soc., 1992, 114, 10068; (b) B. P. Warner, B. L. Scott and C. J. Burns, Angew. Chem., Int. Ed., 1998, 37, 959.

18 M. J. Sarsfield, H. Steele, M. Helliwell and S. J. Teat, Dalton Trans., $2003,3443$.

19 (a) W. J. Oldham, S. M. Oldham, B. L. Scott, K. D. Abney, W. H. Smith and D. A. Costa, Chem. Commun., 2001, 1348; (b) S. A. Mungur, S. T. Liddle, C. Wilson, M. J. Sarsfield and P. L. Arnold, Chem. Commun., 2004, 2738.

20 J. C. Berthet, M. Nierlich and M. Ephritikhine, Dalton Trans., 2004, 2814.

21 B. Masci, M. Nierlich and P. Thuéry, New J. Chem., 2002, 26, 120.

22 J. A. Denis, M. R. Lin, B. L. Scott, B. W. Eichhorn and W. H. Runde, Inorg. Chem., 2001, 40, 3389. 